\title{
SUCCESS RATE OF THE ENDODONTIC TREATMENT OF YOUNG PERMANENT TEETH WITH CALCIUM HYDROXIDE
}

\author{
J. Vojinović, ${ }^{*}$ S. Čupić, O. Dolić, Đ. Mirjanić, S. Sukara, M. Obradović \\ University of Banja Luka, Faculty of Medicine, Department of Dentistry, \\ Republic of Srpska, B\&H
}

\begin{abstract}
The paper presents a comparative analysis of success rates of treatment of apical periodontitis with Calcium Hydroxide paste compared to the conventional method. The course of recovery was observed with 185 treated permanent teeth with either finished or unfinished root growth, of which 68 teeth fall within the control group. It is noted that the success rate of the group treated with Calcium Hydroxide is considerably higher $(85 \%$ as opposed to $67 \%$ ).
\end{abstract}

Keywords: young teeth, apical periodontitis, calcium hydroxide.

\section{INTRODUCTION}

Calcium Hydroxide (hereinafter $\mathrm{CH}$ ) is one of the most important medicaments used in treatments of pulp conditions and apical periodontitis. Its application was recommended as early as by Herman in 1920s [1] when it was recommended to be used for pulp covering and root canal final filling, primarily because of its anti-bacterial characteristics of high $\mathrm{pH}$. Early clinical results led to histopathological studies that showed forming of mineralized tissue barrier under $\mathrm{CH}$ paste, whose $\mathrm{pH}$ was about 12 [2,3]. In the sixties of $20^{\text {th }}$ century, experiences in pulp covering were studied on the various levels with various authors revealing successes in endodontic treatment of then unsolvable problem in children' dentistry - endodontic treatment of teeth with unfinished root growth $[4,5]$. Later, application of $\mathrm{CH}$ in therapy of teeth with finished root growth [5-8] began, and in $80 \mathrm{~s}$ this material was proclaimed to have a high power in restraining root tissue inflammatory absorption. Numerous in vivo and in vitro experiments were done with people to establish effects of sporadic clinical trials. The following theories of possible effects of $\mathrm{CH}$ paste as a canal filler $[4,5,7,9$, 10,11] were established: 1 . Direct stimulation of forming of tissue 2. Anti-bacterial effect 3 . Indirect stimulation of recovery because coagulation necrosis provoked by $\mathrm{CH}$ paste enables smooth recovery. Over the past decades, apart from serving as a temporary filling during endodontic treatment, $\mathrm{CH}$ became an ingredient of final cement filling [7,8,13]. Although numerous trials point out at high regenerative potential of this material and of medicaments, there are still few clinical trials with children the aim of which was to monitor, over a long period of time, success in curing periapical destructions.

Therefore, with this study we wished to accomplish the following:

- prove success of clinical endodontic treatment of apical periodontitis with children with application of $\mathrm{CH}$ paste as temporary filling

- compare its success with conventional therapy

- find out to what extent recovery stimulated with $\mathrm{CH}$ paste can neutralize consequences of low quality filling

- establish to which degree other parameters like gender, extent of bone loss, disease etiology can affect the recovery process

\section{MATERIAL AND METHODOLOGY}

The process of recovery of 185 teeth treated for apical periodontitis, divided in two groups-experimental and control, was analyzed

1. Teeth treated with temporary $\mathrm{CH}$ paste filling fall within the experimental group and include

- Group with finished root growth

- Group with unfinished root growth

2. Teeth treated with conventional endodontic therapy with Walkoff paste (Jodoform Chlymski) periapical filling comprise the control group.

\begin{tabular}{|l|l|l|l|c|}
\hline & $\begin{array}{l}\text { Root } \\
\text { growth } \\
\text { finished }\end{array}$ & $\begin{array}{l}\text { Root growth } \\
\text { unfinished }\end{array}$ & $\begin{array}{l}\text { Control } \\
\text { group }\end{array}$ & Total \\
\hline Male & 31 & 18 & 25 & 74 \\
\hline Female & 53 & 15 & 43 & 111 \\
\hline Total & 84 & 33 & 68 & 185 \\
\hline
\end{tabular}


Patients in study were aged between 10 and 20. The longest period of observation was 5 years, the shortest 6 months after final filling, whereof $9 \%$ of periods of observation were less than 12 months, $48 \%$ from $12-36$ months and $49 \%$ over 36 months.

Endodontic treatment was conducted by different dentists in public and private practice (faculty, dentists undergoing specialized studies under supervision of mentors). Conventional mechanic and medicament treatment was used to decrease secretion

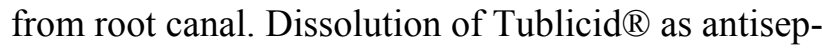
tic was applied in duration of 1 minute before the inception of the treatment. During the time interval between visits there was no use of antiseptics, instead of them Panthenol dissolution ${ }^{\circledR}$ impregnated pad was used. After the root canal secretion had subsided the root canal was filled up with a fresh prepared sterile $\mathrm{CH}$ paste, which was replaced after one week and then after 30 days till the end of the treatment. In cases where root growth was finished this happened after 30 days, in those with unfinished root growth it lasted until the application of medicament therapy for stimulation of root growth or root growth natural finalization which was proved by $\mathrm{x}$-rays or clinically.

In control group a conventional therapy was applied using apical filling of Jodofrom Chlymski paste, used in everyday practice. It was used in the treatment of the teeth of unfinished root growth only. Analysis of success was done by precise methodology published by Vojinovic et al (1987), [4] based on both subjective and objective parameters.

A first criterion comprised the absence of anamnesis symptoms like pain, difficulty at chewing, followed by absence of medical signs obtained through examination, palpations in apex area and horizontal and vertical percussion. The most important criterion was comparing retro alveolar x-ray images taken prior to treatment with the ones made during the last control visit. X-ray images were analyzed by modified Andreasen and Rud analysis from 1972, [9]. Success of the therapy was defined as:

1. Complete loss of apical lesion with preserved lamina dura and identical width of periodontal area in root surroundings

2. Preserved continuum of lamina dura with crescent-like enlargement of periodontal area with obvious signs of disappearance of bone destruction

The following parameters were used to define the failure criteria:

1. Reduction of bone loss, but discontinuation of lamina dura and obscurely defined periodontal area

2. Increase of bone loss in comparison with the first image
3. Presence of fistula

4. Presence of acute progression

All obtained parameters were statistically processed. Significance of discovered discrepancies between experimental and control group was measured by) $\left({ }^{2}\right.$ test.

\section{RESULTS}

Usage of $\mathrm{CH}$ as regenerative temporary filling gives, to a statistically significant degree, better results in recovery processes compared to the usage of conventional methodology. (Chart 1). It was not noted that gender, etiology (untreated caries, secondary caries, injuries and similar) and presence of medical signs prior to therapy had any influence. It was not noted that root growth stage influenced healing progress. Clinical relapses (acute or with fistula) and lesion increase as seen by X-ray, were noted with the control group.

Chart 2 shows healing stages in both groups dependent upon the final filling quality. The results doubtlessly show that previous stimulation of regeneration by usage of $\mathrm{CH}$ paste can significantly neutralize even a low quality filling. Identified discrepancies are statistically significant. $(\mathrm{P}<0.05)$.

It was then analyzed to what extent the time after the final filling could influence healing proportion. The results clearly show that the 6 months period is not enough, and that it is optimal to have 12 months elapsed before getting a clear picture of recovery of all tissues of apical periodontium. Therefore, success interpretation will require some patience.

\section{COMMENTS}

The studies dealing with success of endodontic therapy vary in the outcomes which is a great deal a result of different approaches in monitoring. Applications of only clinical or radiography criteria proved to be imprecise and it was only the combination of both that provided a clearer picture [4]. Earlier studies show that the percentage of healing from $31 \%$ to $85 \%$ and bad prognosis is present with radiography damaged periapical bone. More recent analyses conducted in the USA on a big sample of over $1,462,936$ endodontically treated teeth show that $97 \%$ remain longer than 8 years [18]. Main causes of failure are bad root canal final fillings and weak restoration of tooth coronary part. Analyses of success of endodontic treatment of young permanent teeth are rare and usually concerned with unfinished root growth [4-8]. 


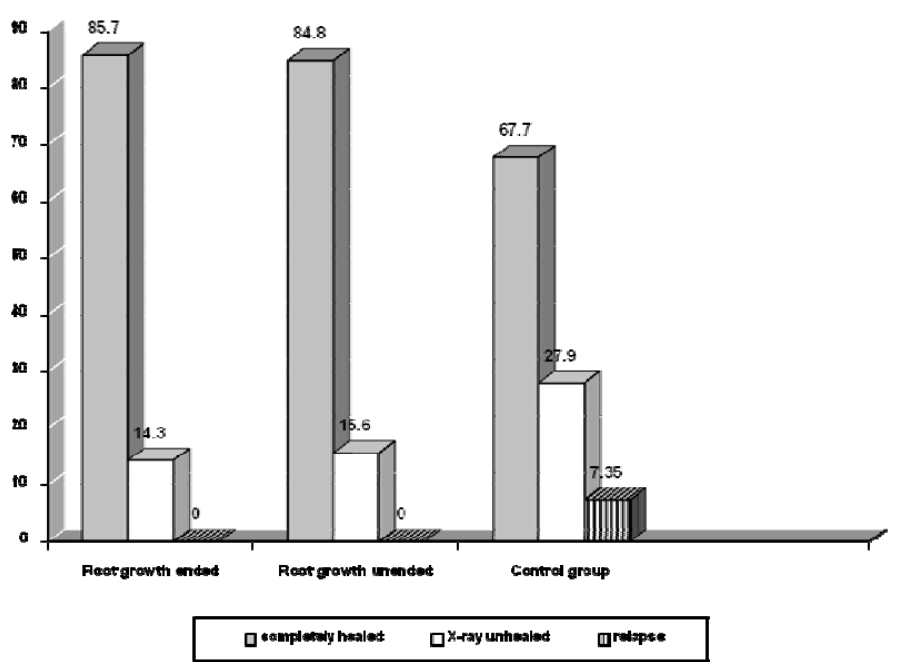

Chart 1. Results of treatments of apical periodontitis in experimental and control group

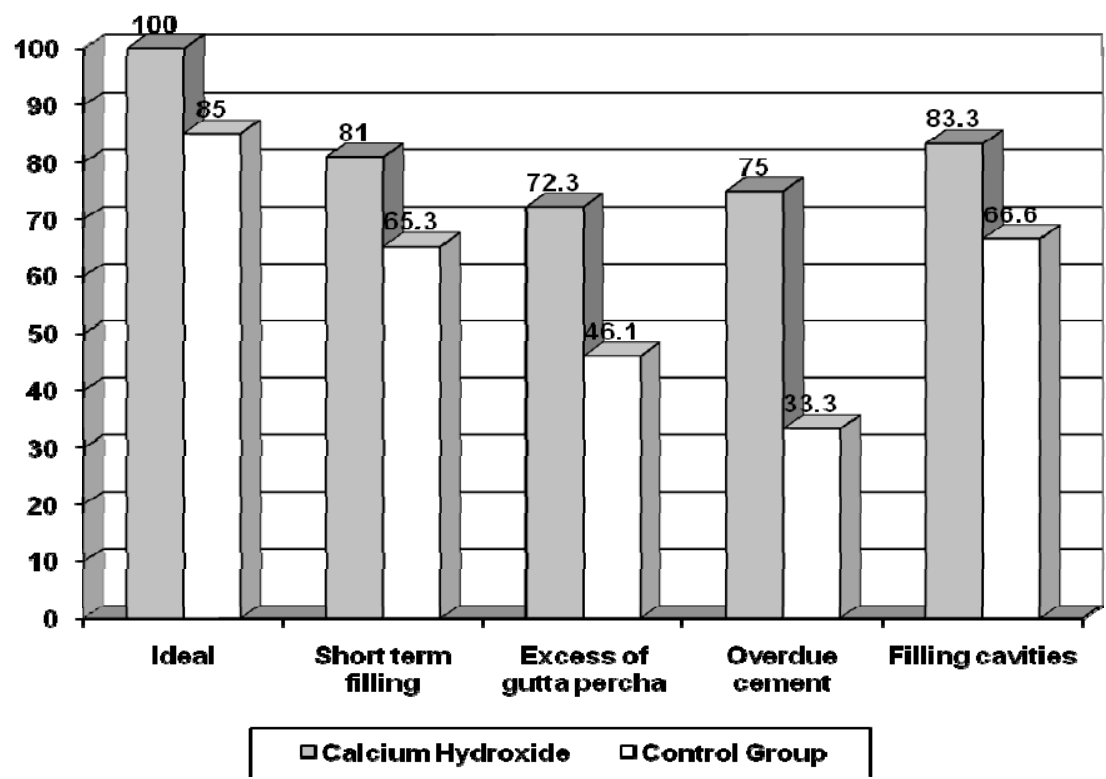

Chart 2. Correlation between healing stage and quality of final filling

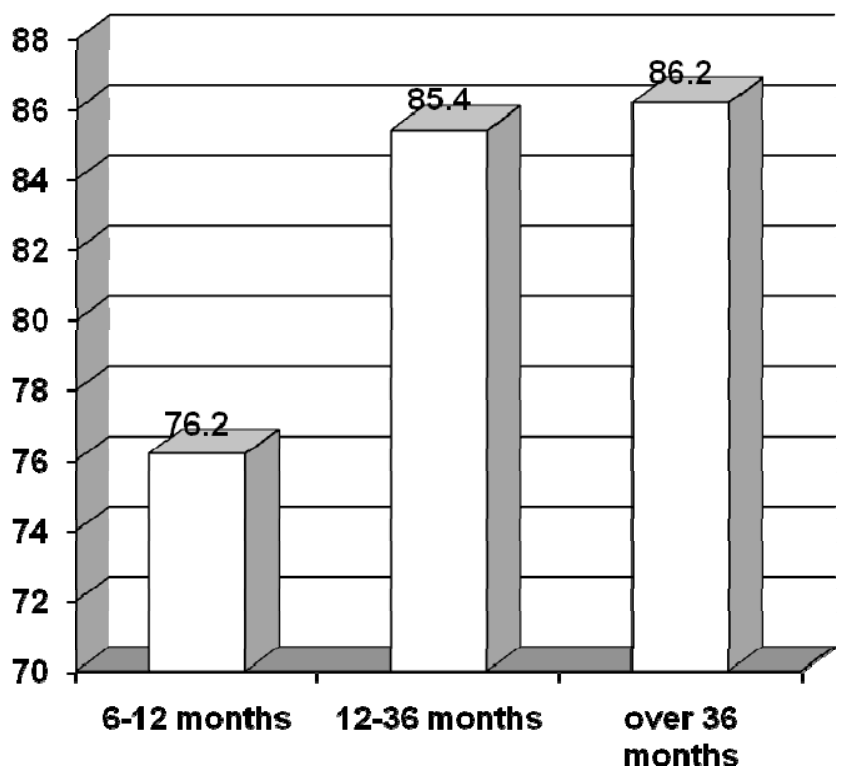

Chart 3. Healing stage and time passed from the final filling 
Outcome of $85.7 \%$ success rate of treatment with finished root growth and $84.8 \%$ with unfinished root growth in our sample fall within the eligible frames of contemporary endodoncy. Absence of statistically significant discrepancies concerned with gender, size of lesion, etiology and presence of medical signs prior to therapy are in line with the already published studies $[4,7,8,17,18]$.

Our analysis indicates that there are much more endodontically treated teeth that have bad filling $(70 \%)$ than are shown in the studies conducted in the developed countries $[4,7,8,18]$, which is in line with low level of development, organizational scheme of public and private sector, and especially with the level of people's awareness and popularity of endodontical therapy. Our regions, according to the WHO data, have the highest rate of lost teeth due to their extraction. All existing clinical and experimental studies prove that low quality final filling has a bad influence on the recovery process of apical periodontium. Thereby, penetration of canal filling periapically is worse than short-term filling $[4,7,8,18]$.

The success rate of $81 \%$ in $\mathrm{CH}$ group of teeth with short-term filling and $72,3 \%$ with teeth with overdue filling indicate that periodontium reacts better to Calcium Hydroxide [4]. Conventional methodology accompanied with ideal filling reveals unsatisfactory results in comparison with $100 \%$ success of Calcium Hydroxide treatment. This further underlines a well-known fact that the strong antiseptics and periapical irritation have an adverse effect on recovery process and, that the cure is successful in spite of their presence, rather than because of their beneficial effects [6-8].

Another issues that is raised is the one of relatively high number of overdue fillings with teeth with finished root growth, because the formation of mineralized barrier is believed to impede such a reaction. We are of the opinion that $\mathrm{CH}$ paste was kept over a relatively short period of time (1 to 3 months) which is not long enough for forming a barrier that would withhold the cement pressure caused by lentula mishandling [4-6].

The biggest number of extensive studies that deal with endodontic treatments indicate that most failures happen already in the first 3 years after final filling. Our studies indicate that interpreting conclusions before 6 months. based on $\mathrm{x}$-ray images. is not reliable enough and that is necessary to wait at least 12 months before it is possible to have proper insight in the ways of recovery.

A significant difference between the number of successful healings of teeth treated with $\mathrm{CH}$ paste and Iodoform-Chlumsky is in line with the existing clinical and experimental researches; according to it the Walkoff methodology is not recommended to be used in everyday practice $[4,5,6,12]$.

\section{CONCLUSIONS}

With the application of temporary filling of the canal root with Calcium Hydroxide paste higher healing rate of apical periodonititis with children is achieved compared to the rate achieved with conventional methodology.

Healing is primarily dependant upon the final filling quality, and if it is within eligible frames, success is $100 \%$.

Where there is low quality final filling, the previously mentioned treatment with $\mathrm{CH}$ paste still produces higher healing rate compared to the use of conventional methodology.

\section{REFERENCES}

[1] B. W. Herman, Biologishe Wurzellbehandlung, Kramer and Co, Frankfurt 1936.

[2] H. A. Zander. Reaction of the Pulp to Calcium Hydroxide, J Dent Res 18 (1939) 373.

[3] R. L. Glass, H. A. Zender, Pulp healing, J.Dental Res 28 (1949) 97.

[4] J. Vojinović, Uticaj kalcijum hidroksida na reparatornu aktivnost apikalnog $i$ lateralnog parodoncijuma. PhD Thesis, Medicinski fakultet u Novom Sadu, 1997.

[5] O. Vojinović, J. Vojinović, M. Aleksijević, R. Stevanović, Endodontsko lečenje stalnih zuba u dece, Medis Net 1999.

[6] O. Vojinović, R. Stevanović, J. Vojinović, Biološki osnovi u endodontskom lečenju zuba sa nezavršenim rastom korena, Nauka, Beograd 1997.

[7] M. Torabinejad, E. Richard, Endodontics Walton 2009, 376-380.

[8] G. Bergenholtz, Textbook of Endodontology, WILEY-BLACKWELL, Oxford, Arress 2010.

[9] J. O. Andreasen, J. Ruda, Correlation between histology and radiography in the assessment of healong after endodontic surgery, J Oral Surgery 1 (1972) 161.

[10] S. Assed, N. F. Paulo, M. R. Leonardo, A. R. Marcos. Effect of calcium hydroxide on bacterial endotoxin in vivo, J Endod, 28 (2002) 94-8.

[11] J. F. Siqueira, H. P. Lopes. Mechanisms of antimicrobial activity of calcium hydroxide: a critical review, Int Endod J, 32 (1999) 361-9. 
[12] L. Castagnola, H. G. Orlay. Treatment of gangrene of the pulp by the Walkoff method, Br Dent J 93 (1952) 93-102.

[13] B. Karadžić, M. Vujašković, Ispitivanje biokompatibilnosti dentalnih materijala za punjenje kanala korena implantiranih u mišićno tkivo pacova, Acta veterinaria 59, 2-3 (2009) 267-276.

[14] C. Estrelaa, D. Decurcioa, A H G Alencara, G. Sydneyb, J. A. Silvaa Efficacy of calcium hydroxide dressing in endodontic infection treatment: a systematic review, Rev. Odonto Sciênc. 23(1), (2008) 82-86.

[15] K. Ramar, J. Mungara, Clinical and radiographic evaluation of pulpectomies using three root canal filling materials: An in-vivo study, Journal of Indian Society of Pedodontics and Preventive Dentistry 28 (1), (2010) 25-29.
[16] P. B. Dixit, S. Achary, I. Prajapati, Calcium hydroxide in management of large periapical lesion, Journal of Nepal Dental Association 10:2 (2009) 125-127.

[17] R. M. C. Travassos, A. Caldas Junior, D. S. Albuquerque, Cohort study of endodontic therapy success, Braz. Dent. J. 14:2 (2003) 109-13.

[18] R. Salehrabi, I. Rotstein, Endodontic Treatment Outcomes in a Large Patient Population in the USA: An Epidemiological Study Journal of Endodontics 30:12 (2004) 846-50.

[19] K. Kerekes, S. Heide, I. Jacobsen, Follow-up examination of endodontic treatment in traumatized juvenile incisors, Journal of Endodotics, $6: 9$ (1980) 744-748.

$\operatorname{son}$

\section{УСПЕХ У ЕНДОДОНТСКОМ ЛЕЧЕњУ МЛАДИХ СТАЛНИХ ЗУБА СА ПАСТОМ КАЛЦИЈУМ-ХИДРОКСИДА}

Сажетак: У раду је приказана упоредна анализа успеха у лечењу апикалних пародонтита са пастом калцијум-хидроксида и класичном методом. Праћен је ток репарације код 185 лечених сталних зуба са завршеним и незавршеним растом корена од којих је 68 припадало контролној групи. Степен исцељења је значајно већи код примене калцијум-хидроксид пасте (85\% према 67\%).

Кључне речи: млади зуби, апексна пародонтопатија, калцијум-хидроксид. 